\title{
PENGARUH BAHAN PENGEKSTRAK DAN TINGKAT KADAR AIR TERHADAP VIABILITAS DAN VIGOR BENIH KAKAO (Theobroma cacao L.)
}

\author{
Effect of Extracted Material and Water Level Rate to Viability and Vigor of Cacao Seed \\ (Theobroma cacao L.)
}

\author{
Suldahna $^{1}$, Hasanuddin ${ }^{2}$, Erida Nurahmi2 ${ }^{2 *}$ \\ ${ }^{1}$ Program Studi Agroteknologi Fakultas Pertanian Universitas Syiah Kuala \\ ${ }^{2}$ Program Studi Agroteknologi Fakultas Pertanian Universitas Syiah Kuala, Darussalam
} 23111

${ }^{*}$ Email Korespondensi :

\begin{abstract}
This research is intended to determine the effect of extracting materials and appropriate levels of water content on cocoa seeds, and whether or not there are any differences between the viability and the vigor of cocoa beans. The research was conducted at the Laboratory of Seed Science and Technology of the Faculty of Agriculture of Syiah Kuala University. The experimental design used was Completely Randomized Design of $3 \times 3$ factorial pattern with $3 x$ replications, so there were 9 treatment combinations and 27 experimental units. The factors studied were extracts consisting of 3 levels, namely: husk ash, sawdust and whiting and three levels of air three levels, namely: 30\%, 25\%, and 15\%. Measurable benchmarks include Growing Potential (PT), Growing Power (DB), Vigor Index (IV), Growth Rate (KCT), Growth Unity (KST), Time Required to Achieve $50 \%$ of Total Relative Germination (T50) and Normal Dry Sprout Weight (BKKN). The results of this study showed that extracting foods are very strong on the viability and strength of the cocoa seeds, which is balanced by the growth potential benchmarks (PT), power growth (DB), growth rate (KCT), growing lavency (KST), the time required to achieve $50 \%$ germination total (T50), vigor index (IV) and normal germination weight (BKKN). Meanwhile, fertility rate grew (KST), time needed to reach 50\% total relative germination (T50), spirit index (IV) and normal dried germination (BKKN). The results of this study can be concluded that there is a very real interaction between the treatment of extracting materials with cocoa beans content levels. The interaction between sawdust and 30\% moisture content is the best combination. Reproduction extracting materials to the effectiveness of increasing viability and vigor of cocoa seeds. The best extraction material is found in the sawdust extracting material. The degree of air hardness to the strength of increased viability and strength of cocoa seed. The best levels of cocoa seed air are found at $30 \%$.
\end{abstract}

Keywords: cocoa, extract, seed

\section{PENDAHULUAN}

Kakao (Theobroma cacao L.) merupakan tanaman perkebunan yang tergolong kedalam famili Sterculiaceae dari genus Theobroma. Tanaman ini berasal dari hutan hujan tropis Amerika
Tengah dan bagian tengah Amerika Selatan tepatnya pada wilayah $18^{0} \mathrm{LU}-15^{0}$ LS. Usaha pengembangan kakao mulanya dirintis oleh bangsa Spanyol ke Benua Afrika dan Asia. Di Indonesia, tanaman kakao di introduksi melalui Filipina ke 
Sulawesi Utara dan sudah dikenal sejak 1560. Tahun 1806, usaha perluasan kakao dimulai lagi di Jawa Timur dan Jawa Tengah (Siregar et al. 2010).

Perhatian pemerintah terhadap usaha tani kakao sangat besar, berbagai usaha telah dilaksanakan untuk perkebunan kakao seperti perluasan areal dan perbaikan teknik budidaya. Tanaman kakao sangat sesuai untuk dijadikan perkebunan rakyat, karena mampu berbunga dan berbuah sepanjang tahun, sehingga dapat menjadi sumber pendapatan harian atau mingguan bagi pekebun, hal ini juga didukung permintaan pasar didalam negeri yang semakin besar seiring dengan terus berkembangnya sektor agroindustri (Pusat Penelitian Kopi dan Kakao Indonesia 2004).

Kakao paling terkenal dengan produk turunannya, berupa coklat. Produk-produk ini dikonsumsi di seluruh dunia, diminati karena rasa yang unik dan aroma yang tidak bisa digantikan oleh produk tanaman lainnya. Kakao merupakan sumber makanan yang kaya polivenol dan memiliki aktivitas antioksidan tinggi dari pada teh dan anggur merah. Beberapa efek menguntungkan dari polivenol adalah seperti anti-karsinogenik, anti-aterogenik, anti-maag, anti-trombotik, anti-inflamasi, kekebalan modulasi, anti-mikroba, efek vasodilatasi dan analgesik (Hii et al. 2009).

Sehubungan dengan meningkatnya permintaan kakao dunia akibat terus meningkatnya kebutuhan, Indonesia terus berupaya meningkatkan produksi dan ekspor kakao. Upaya peningkatan produksi dilakukan dengan berbagai cara di antaranya penanaman areal baru dan peremajaan. Perluasan dan peremajaan tanaman kakao tersebut memerlukan benih berkualitas dalam jumlah besar (Pusat Penelitian Kopi dan Kakao Indonesia 2004).

Salah satu kendala penting dalam rangka penyediaan benih berkualitas adalah bahwa benih kakao merupakan benih yang berdaging juga berair (pulp).
Pada saat masak fisiologis maupun masak morfologis kandungan air benih masih sangat tinggi, benih diselimuti oleh pulp yang saling melekat pada ruang-ruang tempat biji tersusun yang mengandung bahan yang bersifat inhibitor.

Zat penghambat perkecambahan (inhibitor) yang menyelimuti permukaan benih harus dihilangkan lebih dahulu sebelum dikeringkan (Kuswanto 2005). Sutopo (2002) juga menyebutkan bahwa banyak zat yang diketahui dapat menghambat perkecambahan salah satunya adalah pulp, yakni cairan buah yang melapisi biji. Untuk itu perlu dicari cara untuk memisahkan benih dari daging buahnya sehingga diperoleh benih yang bermutu baik. Pemisahan daging buah ini dapat dilakukan dengan bahan pengekstrak.

Perlakuan bahan pengekstrak pada daging benih bertujuan untuk mendapatkan benih yang bermutu, selain itu juga dapat mengendalikan serangan hama dan penyakit. Daging yang menyelimuti biji merupakan media yang baik bagi perkembangbiakan mikroorganisme seperti tumbuhnya jamur dan serangan semut. Jika daging buah tidak dibersihkan akan menjadi tempat yang baik bagi perkembangan mikroorganisme dan mempercepat kerusakan serta kemunduran benih. Sukarman dan Rusmin (2002) mengemukakan bahwa ekstraksi dilakukan segera setelah buah dipanen supaya benih tidak terinfeksi cendawan maupun terserang serangga.

Benih kakao dapat rusak bila tidak segera dihilangkan cairan pulpnya. Pembuangan pulp (ekstraksi) yang menempel pada biji kakao dapat dilakukan dengan beberapa cara antara lain menggosok benih dengan pasir dan serbuk gergaji. Cara lain biasa juga digunakan dengan merendam biji selama 20 menit didalam air kapur (25 g / L air), kemudian digosok dengan tangan sehingga pulp akan mudah dilepas (Siregar et al. 2002). 
Hasil penelitian sebelumnya menunjukkan bahwa perlakuan ekstraksi selain mampu menghindari benih dari serangan cendawan, juga mampu mempertahankan viabilitas benih dibandingkan dengan benih tanpa perlakuan ekstraksi (Supianti 2000). Hilangnya lendir dari benih menjadikan kulit benih menjadi permeabel terhadap air dan oksigen sehingga dapat meningkatkan viabilitas dan vigor benih. Air dan oksigen merupakan syarat utama untuk perkecambahan. Pranoto et al. (1990) menyatakan bahwa air merupakan kebutuhan dasar yang utama untuk perkecambahan, fungsi air adalah untuk melunakkan kulit benih, mengencerkan protoplasma sehingga terjadi proses-proses metabolit di dalam benih dan mentranslokasikan cadangan makanan ke titik tumbuh yang diperlukan.

Dengan demikian sebelum benih dikeringkan pulp yang ada harus dihilangkan terlebih dahulu sebelum digunakan yaitu dengan menggunakan air kapur, pasir, serta arang sekam kemudian benih dicuci dengan air hingga bersih dan bebas dari lendir (Kuswanto 2005).

Selain masalah di atas tersebut hal terpenting dalam rangka penyediaan benih berkualitas adalah bahwa benih kakao merupakan benih rekalsitran. Benih rekalsitran bersifat tidak tahan jika dikeringkan dan peka terhadap suhu dan kelembaban yang rendah. Kondisi tersebut dapat menyebabkan benih kakao mengalami kerusakan akibat kontaminasi mikrobial, benih berkecambah selama penyimpanan dan kekurangan oksigen. Selain itu, pengeringan juga dapat menyebabkan kerusakan benih (King dan Roberts 1979). Karakteristik ini menyebabkan benih kakao mengalami penurunan kualitas dengan cepat bila kadar air benih turunan melampaui batas kadar air kritisnya.

Kematian dan kemunduran benih rekalsitran dapat disebabkan karena penurunan tingkat kadar air yang relatif rendah. Chin (1990), mengemukakan bahwa benih kakao mempunyai kadar air kritis yang relatif tinggi, apabila kadar air benih diturunkan sampai di bawah kadar air kritis $(12 \%$ - 31\%) dapat menyebabkan viabilitas benih kakao menurun dengan cepat, bahkan dapat menyebabkan kematian. Penurunan tingkat kadar air benih kakao dapat menyebabkan deteriorasi. Terjadinya deteriorasi benih diduga akibat adanya degradasi mekanisme pemicu perkecambahan internal di dalam benih. Penurunan aktivitas metabolisme pada benih yang mundur menyebabkan viabilitasnya menurun. Secara fisiologis, terjadinya deteriorasi akibat kadar air terindikasi melalui menurunnya daya kecambah (Robi 1996) sedangkan secara biokimia dapat terlihat dari meningkatnya kebocoran membran (Winarsih 1994).

$$
\text { Bewley dan Black (1994) }
$$
mengemukakan bahwa penurunan kadar air benih yang cukup tinggi akan menyebabkan terjadinya pengeringan di bagian embrio sehingga menekan aktivitas ribosom dalam mensintesis protein sehingga viabilitasnya menurun. Kadar air yang terlalu rendah akan mengakibatkan kerusakan komponen sub seluler yaitu perubahan struktur enzim, struktur protein dan penurunan integritas membran sel.

Permasalahan pada benih rekalsitran bukan hanya pada kadar air rendah, kadar air yang tinggi dapat pula menimbulkan kerusakan pada benih. Kandungan air yang tinggi pada benih rekalsitran menyebabkan benih tersebut peka terhadap desikasi dan chilling injury. Kandungan air yang terlalu tinggi dapat menimbulkan kerusakan apabila disimpan pada suhu di bawah nol. Suhu tersebut menyebabkan terjadinya freezing injury dan pembentukan kristal es dalam sitoplasma sel (Copeland dan McDonald 1995).

Benih kakao memiliki kadar air serta kandungan lemak yang tinggi yaitu lemak nabati sekitar $50 \%$ yang terdiri dari 7 macam asam lemak yaitu asam palmitat 
$24.8 \%$, stearat $33.0 \%$, oleat $33.1 \%$, linoleat $3.2 \%$, arakhidonat $0.8 \%$, sehingga bila diturunkan kadar airnya maka proses respirasi akan berjalan sangat cepat sehingga cadangan makanan akan habis, yang mengakibatkan embrio mati dan juga kandungan lemak akan teroksidasi sehingga menyebabkan kematian benih (Katriani 2010).

Mengingat benih kakao merupakan salah satu jenis benih rekalsitran dan besarnya pengaruh kadar air pada benih rekalsitran maka perlu diketahui tingkat kadar air pada benih kakao. Tingkatan kadar air benih akan merupakan petunjuk dalam mengelola benih rekalsitran tersebut. Dengan mengetahui dinamika tersebut maka penanganan pada benih akan lebih mudah.

Pengujian benih ditujukan untuk mengetahui mutu atau kualitas benih. Informasi tersebut tentunya akan sangat bermanfaat bagi produsen, penjual maupun konsumen benih. Karena mereka bisa memperoleh keterangan yang dapat dipercaya tentang mutu atau kualitas dari suatu benih. Berdasarkan uraian diatas, maka perlu dilakukan penelitian lebih lanjut mengenai bahan pengekstrak yang sesuai dengan kadar air yang berbeda terhadap viabilitas benih kakao.

Penelitian ini bertujuan untuk mengetahui pengaruh bahan pengekstrak dan tingkat kadar air yang sesuai pada benih kakao, serta ada tidaknya interaksi antara kedua faktor tersebut terhadap viabilitas dan vigor benih kakao.

\section{BAHAN DAN METODE PENELITIAN}

\section{Tempat dan Waktu}

Penelitian dilaksanakan di laboratorium Ilmu dan Teknologi Benih Fakultas Pertanian Universitas Syiah Kuala Darussalam Banda Aceh.

\section{Bahan dan Alat}

Bahan yang digunakan dalam penelitian ini adalah : Benih kakao varietas
UAH (Upper Amazone Hybrid), diperoleh dari kebun rakyat Desa Lamtamot Kecamatan Lembah Seulawah Kabupaten Aceh Besar. Kantong benih untuk membalut benih di dalam wadah stoples pada saat menurunkan kadar air benih kakao. Silica gel untuk menurunkan tingkat kadar air benih kakao. Pasir sebagai media perkecambahan. Arang sekam, serbuk gergaji dan kapur sirih untuk mengekstrak benih kakao. Pestisida Delsen MX-200 dengan konsentrasi $3 \mathrm{~g} / \mathrm{L}$ air.

Alat -alat yang digunakan adalah: Grainer-11 untuk mengukur tingkat kadar air benih, timbangan analitik untuk menimbang berat kering kecambah normal, stoples sebagai wadah pada saat menurunkan kadar air benih kakao. Pisau untuk membelah buah kakao pada saat pengambilan biji, baskom plastik digunakan sebagai wadah ekstraksi benih kakao, wadah perkecambahan untuk perkecambahan benih, hand sprayer untuk menyiram benih setelah penanaman dan selotip sebagai perekat untuk melapisi stoples agar kedap udara serta ayakan 8 mess.

\section{Pelaksanaan Penelitian}

Penelitian ini menggunakan Rancangan Acak Lengkap (RAL) pola Faktorial 3 x 3 dengan tiga ulangan yang terdiri atas dua faktor yaitu bahan pengekstrak benih (M) dan tingkat kadar air benih $(\mathrm{K})$. Bahan pengekstrak benih terdiri atas 3 taraf yaitu : $\mathrm{M}_{1}=$ Arang sekam, $\mathbf{M}_{2}=$ Serbuk gergaji, $\mathrm{M}_{3}=$ Kapur sirih sedangkan faktor tingkat kadar air benih $(\mathrm{K})$ terdiri atas 3 taraf yaitu: $\mathrm{K}_{1}$ $=30 \%, \mathrm{~K}_{2}=25 \%, \mathrm{~K}_{3}=15 \%$.

Benih jenis Forastero varietas UAH (Upper Amazone Hybrid) yang sudah matang diambil dari batang utama yang ditandai dengan kulit buah yang telah berwarna kuning, jika buah diketuk akan mengeluarkan suara dan bila buahnya dibelah pulpnya belum kering karena bila pulp telah kering biasanya biji telah berkecambah didalam buah (Sunanto, 
2002). Biji diambil dari bagian tengah buah, tiap-tiap buah dibagi menjadi tiga bagian yaitu pangkal, tengah dan ujung. Benih yang diambil sebagai bahan tanam yaitu sebanyak $1 / 3$ dari buah pada bagian tengah.

\section{Perlakuan Ekstraksi Benih}

Eksraksi benih dilakukan dengan cara membelah buah secara membujur menggunakan pisau. Pembelahan dilakukan dengan cara hati-hati agar tidak merusak benih, kemudian benih dikeluarkan dari buahnya. Bahan-bahan yang digunakan untuk mengekstrak benih kakao adalah arang sekam, serbuk gergaji dan kapur sirih. Untuk memisahkan benih dari pulpnya dilakukan cara berikut:

1. Perlakuan pertama, benih yang masih diselimuti pulp dibersihkan langsung dengan arang sekam lalu diremasremas atau digosok dengan tangan hingga bersih selanjutnya benih dicuci dengan air dan ditiriskan selama 15 menit.

2. Perlakuan kedua, benih dibersihkan dengan menggunakan serbuk gergaji lalu diremas atau digosok dengan tangan hingga bersih selanjutnya dicuci dengan air dan ditiriskan selama 15 menit.

3. Perlakuan ketiga, benih direndam dengan air kapur $25 \mathrm{~g} / \mathrm{L}$ air selama 20 menit lalu, dicuci dengan air hingga bersih dan ditiriskan selama 15 menit.

\section{Penentuan Kadar Air Benih Kakao}

Penentuan tingkat kadar air benih dilakukan dengan menurunkan kandungan air benih pada taraf $30 \%, 25 \%$ dan $15 \%$. Bahan yang digunakan untuk menurunkan tingkat kadar air benih adalah silica gel. Benih kakao yang telah di ekstrak dimasukkan kedalam kantong benih, kantong berisikan benih tersebut dimasukkan kedalam stoples yang telah diisi silica gel sebanyak 200 g/stoples. Kemudian stoples ditutup rapat dan diberi perekat (selotip) sehingga kedap udara.
Pengukuran tingkat kadar air dilakukan dengan menggunakan alat ukur Grainer11. Media tanam diayak dengan ayakan berukuran 8 mess dan dimasukkan kedalam wadah perkecambahan setinggi 15 $\mathrm{cm}$. Benih dikecambahkan sebanyak 25 butir per baskom perkecambahan dengan posisi tegak dan bakal radikula (bagian besar dari benih) berada pada bagian bawah. Biji ditanam dengan jarak $3 \mathrm{~cm}$ x 5 $\mathrm{cm}$.

\section{Parameter Pengamatan}

Pengamatan dilakukan terhadap viabilitas potensial dan vigor kekuatan tumbuh. Untuk peubah viabilitas potensial digunakan tolok ukur potensi tumbuh, daya berkecambah dan bobot kering kecambah normal sedangkan peubah vigor kekuatan tumbuh terdiri atas kecepatan tumbuh, keserempakan tumbuh, Indeks vigor dan $\mathrm{T}_{50}$.

\section{HASIL DAN PEMBAHASAN}

\section{Pengaruh Bahan Pengekstrak terhadap Viabilitas dan Vigor Benih Kakao}

Bahan pengekstrak berpengaruh sangat nyata terhadap viabilitas dan vigor benih kakao yang diamati berdasarkan tolok ukur potensi tumbuh (PT), daya berkecambah (DB), kecepatan tumbuh $\left(\mathrm{K}_{\mathrm{CT}}\right)$, keserampakan tumbuh $\left(\mathrm{K}_{\mathrm{ST}}\right)$, waktu yang dibutuhkan untuk mencapai 50\% dari total perkecambahan relatif $\left(\mathrm{T}_{50}\right)$, indeks vigor (IV), dan berat kering kecambah normal (BKKN). Rata-rata tolok ukur yang dapat diamati pada perlakuan bahan pengekstrak dapat dilihat pada Tabel 1.

Tabel 1. dapat dilihat bahwa perbedaan bahan pengekstrak diikuti oleh perbedaan secara signifikan nilai viabilitas dan vigor benih kakao berdasarkan tolok ukur potensi tumbuh, daya berkecambah, indeks vigor, kecepatan tumbuh, keserampakan tumbuh, waktu yang dibutuhkan untuk mencapai $50 \%$ dari total perkecambahan relatif dan berat kering kecambah normal. Nilai tolok ukur potensi 
tumbuh, daya berkecambah, indeks vigor, kecepatan tumbuh, keserampakan tumbuh dan berat kering kecambah normal tertinggi diperoleh pada benih yang di ekstrak dengan serbuk gergaji $\left(\mathrm{M}_{2}\right)$ dengan nilai masing-masing potensi tumbuh 61.4 $\%$, daya berkecambah $53.05 \%$, kecepatan tumbuh $10.78 \%$ etmal, keserampakan tumbuh $44.24 \%$ etmal, indeks vigor 29.20 $\%$, dan berat kering kecambah normal 20.51 gram, apabila dibandingkan dengan benih yang di ekstrak dengan bahan sekam
$\left(\mathrm{M}_{1}\right)$ dan kapur sirih $\left(\mathrm{M}_{3}\right)$ secara statistik nilainya berbeda. Perbedaan bahan pengekstrak juga diikuti oleh penurunan waktu yang dibutuhkan untuk mencapai $50 \%$ dari total perkecambahan relatif. Benih yang diekstraksi dengan serbuk gergaji $\left(\mathrm{M}_{2}\right)$ menghasilkan waktu yang dibutuhkan untuk mencapai $50 \%$ dari total perkecambahan relatif nyata lebih singkat di banding benih yang di ekstrak dengan menggunakan arang sekam $\left(\mathrm{M}_{1}\right)$ dan kapur $\operatorname{sirih}\left(\mathrm{M}_{3}\right)$.

Tabel 1. Rata-rata tolok ukur viabilitas dan vigor benih kakao pada masing- masing jenis bahan pengekstrak benih

\begin{tabular}{|c|c|c|c|c|c|c|c|}
\hline \multirow{3}{*}{ Perlakuan } & \multicolumn{7}{|c|}{ Tolok Ukur yang Diamati } \\
\cline { 2 - 8 } & $\begin{array}{c}\mathrm{PT} \\
(\%)\end{array}$ & $\begin{array}{c}\mathrm{DB} \\
(\%)\end{array}$ & $\begin{array}{c}\text { KCT } \\
(\% \text { etmal })\end{array}$ & $\begin{array}{c}\text { Kst } \\
(\% \text { etmal })\end{array}$ & $\begin{array}{c}\mathrm{T}_{50} \\
(\text { hari })\end{array}$ & $\begin{array}{c}\text { IV } \\
(\%)\end{array}$ & $\begin{array}{c}\text { BKKN } \\
(\text { gram })\end{array}$ \\
\hline \multirow{2}{*}{$\mathrm{M}_{1}$} & $59.85 \mathrm{~b}$ & $45.39 \mathrm{~b}$ & $9.64 \mathrm{~b}$ & $32.29 \mathrm{~b}$ & $23.96 \mathrm{~b}$ & $20.42 \mathrm{~b}$ & $25.44 \mathrm{~b}$ \\
& $(67.44)$ & $(52.78)$ & 3.34 & 32.00 & $(16.49)$ & $(16.00)$ & $(18.45)$ \\
\hline \multirow{2}{*}{$\mathrm{M}_{2}$} & $61.4 \mathrm{~b}$ & $53.05 \mathrm{c}$ & $10.78 \mathrm{c}$ & $44.24 \mathrm{c}$ & $22.95 \mathrm{a}$ & $\begin{array}{c}29.20 \mathrm{c} \\
(26.67)\end{array}$ & $\begin{array}{c}26.93 \mathrm{c} \\
(20.51)\end{array}$ \\
\hline \multirow{2}{*}{$\mathrm{M}_{3}$} & $45.36 \mathrm{a}$ & $40.12 \mathrm{a}$ & $8.67 \mathrm{a}$ & $28.34 \mathrm{a}$ & $24.61 \mathrm{c}$ & $14.52 \mathrm{a}$ & $22.05 \mathrm{a}$ \\
& $(52.00)$ & $(44.89)$ & 2.71 & 25.33 & $(17.34)$ & $(9.33)$ & $(14.09)$ \\
\hline BNJ 0.05 & 6.88 & 3.06 & 0.52 & 3.35 & 0.50 & 3.53 & 1.36 \\
\hline
\end{tabular}

Keterangan :

$\mathrm{PT}=$ Potensi Tumbuh $\quad \mathrm{DB}=$ Daya Berkecambah

IV $=$ Indeks Vigor $\quad$ KcT $=$ Kecepatan Tumbuh

Kst $=$ Keserampakan tumbuh $\mathrm{T}_{50}=$ Total perkecambahan relatif $50 \%$

BKKN = Bobot Kering Kecambah Normal

Tingginya nilai potensi tumbuh, daya berkecambah, indeks vigor, kecepatan tumbuh, keserampakan tumbuh, waktu yang dibutuhkan untuk mencapai $50 \%$ dari total perkecambahan relatif dan berat kering kecambah normal erat kaitannya dengan jenis bahan pengekstrak yang digunakan sehingga mempengaruhi mutu fisik benih kakao. Hal ini diduga karena ekstraksi benih menggunakan bahan serbuk gergaji menghasilkan benih yang lebih kesat dan bersih dari lendir dibanding bahan pengekstrak sekam dan kapur sirih. Hilangnya pulp atau lendir yang menyelimuti benih menjadikan benih permeabel terhadap oksigen sehingga dapat meningkatkan viabilitas dan vigor benih kakako (Pranoto et al. 1990).

Ekstraksi benih menggunakan arang sekam mampu menghilangkan pulp yang menempel pada kulit benih namun sisa pulp sebagian masih menempel dan lengket pada benih meskipun telah dibilas dengan air sehingga mutu fisik benih menjadi kurang baik, namun sudah cukup baik untuk meningkatkan viabilitas dan vigor benih kakao. Sedangkan perlakuan perendaman benih dalam air menggunakan kapur sirih belum mampu menghilangkan lendir yang menempel pada benih kakao dan warna benih kakao yang dihasilkan menjadi buram. Benih kakao yang masih diselimuti oleh lendir 
diperkirakan dapat berpengaruh buruk terhadap perkecambahan sehingga menurunkan viabilitas vigor benih kakao. Hal ini diduga karena masih adanya lendir atau pulp yang menempel pada kulit benih setelah diekstrak sehingga saat penanaman dapat menghambat perkecambahan dan menjadi media mikroorganisme yang dapat menurunkan viabilitas benih. Menurut Soetisna et al. (1985), benih jeruk yang diselimuti oleh pulp dapat menghambat pertukaran gas dan air didalam benih ke lingkungannya, sehingga dapat menghambat perkecambahan. Hasil penelitian menunjukkan bahwa benih jeruk dapat berkecambah dengan cepat jika kulit benih jeruk dilepas dari benihnya.

Swarbrick (1965), menyatakan lendir yang mengelilingi benih kakao adalah penghambat perkecambahan. Perkecambahan dihambat secara osmotik karena adanya gula dalam lendir (King dan Roberts 1980). Sementara Ibanez dan Cases (1963) menyatakan bahwa perkecambahan benih tidak terjadi disebabkan oleh kerusakan embrio dan gangguan respirasi akibat adanya gula dan alkohol yang terkandung dalam lendir yang menyelimuti benih kakao. Gula dan alkohol tersebut adalah laktosa, maltose, isopropanol dan ettyilene glycol.

Bahan pengekstrak berpengaruh sangat nyata terhadap tolok ukur potensi tumbuh, daya berkecambah, indeks vigor kecepatan tumbuh, keserempakan tumbuh, waktu yang dibutuhkan untuk mencapai $50 \%$ dari total perkecambahan relatif dan berat kering kecambah normal. Hal ini berarti semua tolok ukur viabilitas dan vigor benih kakao tersebut sengat peka terhadap berbagai jenis bahan pengekstrak yang digunakan untuk benih kakao.

\section{Pengaruh Tingkat Kadar Air Benih terhadap Viabilitas dan Vigor Benih Kakao}

Perbedaan tingkat kadar air benih kakao berpengaruh sangat nyata terhadap viabilitas dan vigor benih kakao berdasarkan tolok ukur potensi tumbuh (PT), daya berkecambah (DB), indeks vigor (IV), kecepatan tumbuh (KcT), keserampakan tumbuh (KsT), waktu yang dibutuhkan untuk mencapai 50\% dari total perkecambahan relatif $\left(\mathrm{T}_{50}\right)$ dan berat kering kecambah normal (BKKN). ). Ratarata tolok ukur yang dapat diamati pada perlakuan tingkat kadar air benih dapat dilihat pada Tabel 2 .

Tabel 2. menunjukkan nilai tolok ukur viabilitas dan vigor benih kakao berbeda secara statistik karena perbedaan tingkat kadar air dalam benih yang digunakan. Potensi tumbuh, daya berkecambah, indeks vigor, kecepatan tumbuh, keserampakan tumbuh, waktu yang dibutuhkan untuk mencapai 50\% dari total perkecambahan relatif dan berat kering kecambah normal yang memiliki tingkat kadar air $30 \%\left(\mathrm{~K}_{1}\right)$ nilainya relatif lebih tinggi dibanding dengan nilai potensi tumbuh, daya berkecambah, indeks vigor, kecepatan tumbuh, keserampakan tumbuh, waktu yang dibutuhkan untuk mencapai $50 \%$ dari total perkecambahan relatif dan berat kering kecambah normal benih yang memliki tingkat kadar air benih 25\% $\left(\mathrm{K}_{2}\right)$ dan tingkat kadar air benih $15 \%\left(\mathrm{~K}_{3}\right)$. Nila potensi tumbuh, daya berkecambah, indeks vigor, kecepatan tumbuh, keserampakan tumbuh, waktu yang dibutuhkan untuk mencapai $50 \%$ dari total perkecambahan relatif dan berat kering kecambah normal secara berurutan adalah $73.48 \%, 64.36 \%$, $13.11 \%$ etmal, $48.37 \%$ etmal, 23.49 hari, $31.31 \%$, dan 25.48 gram. Hasil penelitian juga menunjukkan bahwa perbedaan tingkat kadar air benih juga diikuti oleh penurunan waktu yang dibutuhkan untuk mencapai $50 \%$ dari total perkecambahan relatif. Benih yang memiliki kandungan air $30 \% \quad\left(\mathrm{~K}_{1}\right)$ menghasilkan waktu yang dibutuhkan untuk mencapai 50\% dari total perkecambahan relatif nyata lebih singkat di banding benih dengan kadar air $25 \%$ $\left(\mathrm{K}_{2}\right)$ maupun dengan kadar air $15 \%\left(\mathrm{~K}_{3}\right)$. Nilai $\mathrm{T}_{50}$ pada $\mathrm{K}_{1}$ adalah 15.90 hari, statistik nilainya berbeda dengan benih yang berasal dari $\mathrm{K}_{2}$ dan $\mathrm{K}_{3}$. 
Tabel 2. Rata-rata tolok ukur viabilitas dan vigor benih kakao pada masing-masing tingkat kadar air

\begin{tabular}{|c|c|c|c|c|c|c|c|}
\hline \multirow[b]{2}{*}{ Perlakuan } & \multicolumn{7}{|c|}{ Tolok Ukur Yang Diamati } \\
\hline & $\begin{array}{l}\text { PT } \\
(\%)\end{array}$ & $\begin{array}{l}\text { DB } \\
(\%)\end{array}$ & $\begin{array}{c}\text { KcT } \\
\text { (\% etmal) }\end{array}$ & $\begin{array}{c}\text { KsT } \\
(\% \text { etmal })\end{array}$ & $\begin{array}{l}\mathrm{T}_{50} \% \\
\text { (hari) }\end{array}$ & $\begin{array}{l}\text { IV } \\
(\%)\end{array}$ & $\begin{array}{l}\text { BKKN } \\
\text { (gram) }\end{array}$ \\
\hline $\mathrm{K}_{1}$ & $\begin{array}{l}73.48 \mathrm{~b} \\
(88.89)\end{array}$ & $\begin{array}{l}64.36 \mathrm{c} \\
(80.00)\end{array}$ & $\begin{array}{c}13.11 \mathrm{c} \\
(5.19)\end{array}$ & $\begin{array}{c}48.37 \mathrm{c} \\
55.56\end{array}$ & $\begin{array}{l}23.50 \mathrm{a} \\
(15.90)\end{array}$ & $\begin{array}{l}31.31 \mathrm{c} \\
(27.56)\end{array}$ & $\begin{array}{l}30.32 \mathrm{c} \\
(25.48)\end{array}$ \\
\hline $\mathrm{K}_{2}$ & $\begin{array}{l}73.43 \mathrm{~b} \\
(87.11)\end{array}$ & $\begin{array}{l}58.98 \mathrm{~b} \\
(72.78)\end{array}$ & $\begin{array}{c}12.37 \mathrm{~b} \\
(4.62)\end{array}$ & $\begin{array}{c}43.33 \mathrm{~b} \\
47.11\end{array}$ & $\begin{array}{l}23.68 \mathrm{a} \\
(16.13)\end{array}$ & $\begin{array}{l}27.71 \mathrm{~b} \\
(22.67)\end{array}$ & $\begin{array}{l}27.27 \mathrm{~b} \\
(20.99)\end{array}$ \\
\hline $\mathrm{K}_{3}$ & $\begin{array}{l}19.70 \mathrm{a} \\
(11.44)\end{array}$ & $\begin{array}{c}15.23 \mathrm{a} \\
(7.11)\end{array}$ & $\begin{array}{l}3.61 \mathrm{a} \\
(0.41)\end{array}$ & $\begin{array}{c}13.17 \mathrm{a} \\
5.33\end{array}$ & $\begin{array}{l}24.35 \mathrm{~b} \\
(17.00)\end{array}$ & $\begin{array}{l}5.13 \mathrm{a} \\
(1.78)\end{array}$ & $\begin{array}{c}14.86 \mathrm{a} \\
(6.58)\end{array}$ \\
\hline $\mathrm{BNJ}_{0,05}$ & 6.88 & 3.06 & 0.52 & 3.35 & 0.50 & 3.53 & 1.36 \\
\hline
\end{tabular}

Keterangan :

PT $=$ Potensi Tumbuh $\quad$ DB $=$ Daya Berkecambah

IV = Indeks Vigor $\quad$ KcT $=$ Kecepatan Tumbuh

Kst $=$ Keserampakan tumbuh $\mathrm{T}_{50}=$ total perkecambahan relatif $50 \%$

BKKN = Bobot Kering Kecambah Normal

Semua tolok ukur yang diamati menunjukkan bahwa perbedaan tingkat kadar air benih kakao yang digunakan memberikan viabilitas dan vigor benih yang berbeda. Hasil pengamatan potensi tumbuh, daya berkecambah, indeks vigor kecepatan tumbuh, keserampakan tumbuh, waktu yang dibutuhkan untuk mencapai $50 \%$ dari total perkecambahan relatif dan berat kering kecambah normal menunjukkan bahwa benih dengan tingkat kadar air $30 \%$ memberikan nilai yang terbaik dibandingkan benih dengan tingkat kadar air $25 \%$ dan $15 \%$. Hal ini diduga erat kaitannya dengan sifat benih kakao yang merupakan benih rekalsitran sehingga memerlukan kandungan yang tinggi untuk dapat berkecambah secara normal. Pranoto et al. (1990) menyatakan bahwa air merupakan kebutuhan dasar untuk perkecambahan, fungsi air adalah untuk melunakkan kulit benih sehingga embrio dan endosperma membengkak yang menyebabkan retaknya kulit benih, memungkinkan pertukaran gas sehingga suplai oksigen dalam benih terjadi, mengencerkan protoplasma sehingga terjadi proses-proses metabolisme dalam benih dan mentranslokasikan cadangan makanan ke titik tumbuh yang diperlukan.

Penelitian ini menunjukkan bahwa penurunan tingkat kadar air pada taraf $25 \%$ yang digunakan maka viabilitas dan vigor benih kakao juga ikut menurun meskipun secara statistik nilainya tidak berbeda dengan kadar air 30\%. Hal ini sejalan dengan penelitian Hor et al. (1984) menyatakan bahwa benih kakao sangat peka terhadap kondisi kekeringan, akan mati jika kadar airnya kurang dari $25 \%$. Bewley dan Black (1985) mengemukakan bahwa penurunan tingkat kadar air pada benih rekalsitran kakao akan mengakibatkan pengeringan embrio, sehingga menekan aktivitas ribosom dalam mensintesis protein. Penurunan aktivitas tersebut mengakibatkan viabilitas benih menurun. Pammenter et al. (1998) menambahkan bahwa bila benih mengalami dehidrasi secara cepat atau lambat menyebabkan terjadinya penurunan viabilitas benih dan meningkatkan kebocoran membran. Semakin lama waktu dehidrasi menyebabkan persentase perkecambahan semakin menurun. 
Penurunan tingkat kadar air pada taraf $15 \%$ mengakibatkan penurunan yang sangat nyata terhadap viabilitas dan vigor benih kakao. Hal ini diduga karena penurunan tingkat kadar air pada taraf yang sangat rendah mengakibatkan hilangnya kemampuan benih untuk berkecambah akibat kehabisan cadangan makanan. Hal ini sesuai dengan pernyataan Chin et al. (1981) menyatakan kadar air sampai dibawah kadar air kritis dapat menyebabkan viabilitas menurun dengan cepat, bahkan dapat menyebabkan kematian benih kakao. Bonner (1996) menambahkan bahwa benih rekalsitran selain tidak toleran pada suhu dan kelembaban rendah juga peka terhadap penurunan kadar air. Penurunan kadar air dapat mempengaruhi perubahan fosiologi dan biokimiawi benih rekalsitran. Bewley dan Black (1994) menambahkan bahwa penurunan kadar air benih yang cukup tinggi akan menyebabkan terjadinya pengeringan di bagian embrio sehingga menekan aktivitas ribosom dalam mensintesis protein sehingga viabilitasnya menurun.

\section{Pengaruh Interaksi antara Bahan Pengekstrak Benih dengan Tingkat Kadar Air Benih terhadap Viabilitas dan Vigor Benih Kakao}

Interaksi antara bahan pengekstrak benih terhadap tingkat kadar air benih menunjukkan pengaruh sangat nyata terhadap daya berkecambah (DB), berat kering kecambah normal (BKKN), kecepatan tumbuh $\left(\mathrm{K}_{\mathrm{C}} \mathrm{T}\right)$, keserampakan tumbuh $\left(\mathrm{K}_{\mathrm{S}} \mathrm{T}\right)$, pengaruh yang nyata terhadap potensi tumbuh (PT), berpengaruh tidak nyata terhadap waktu yang dibutuhkan untuk mencapai $50 \%$ total perkecambahan $\left(\mathrm{T}_{50}\right)$ dan indeks vigor (IV). Rata-rata nilai potensi tumbuh, daya berkecambah, berat kering kecambah normal, kecepatan tumbuh dan keserampakan tumbuh pada masing- masing pengaruh bahan pengekstrak benih disajikan dalam Tabel 3.

Tabel 3 memperlihatkan potensi tumbuh dari masing-masing bahan pengekstrak benih berbeda dengan adanya tingkat kadar air benih kakao. Interaksi antara bahan pengekstrak dan kadar air benih terlihat bahwa pada perlakuan ekstraksi menggunakan sekam $\left(\mathrm{M}_{1}\right)$ menunjukkan bahwa semakin tinggi kadar air sampai batas tertentu dapat menaikkan potensi tumbuh tanaman kakao dari $80 \%$ pada kadar air $25 \%\left(\mathrm{~K}_{2}\right)$ dan menjadi $79.05 \%\left(\mathrm{~K}_{1}\right)$ pada tingkat kadar air $30 \%$ meskipun secara statistik menunjukkan keduanya tidak berbeda nyata. Tetapi penurunan kadar air pad taraf $15 \%$ menyebabkan potensi tumbuh turun drastis menjadi $19.83 \%$ yang berbeda nyata dengan potensi tumbuh pada kadar air $25 \%$ $\left(\mathrm{K}_{1}\right)$ dan $30 \%\left(\mathrm{~K}_{2}\right)$.

Demikian halnya pada bahan pengekstrak serbuk gergaji $\left(\mathrm{M}_{2}\right)$ dimana semakin meningkatnya kadar air benih semakin meningkat nilai potensi tumbuh, dimana peningkatan tingkat kadar air pada taraf $25 \%$ sampai $30 \%$ potensi tumbuh meningkat menjadi $83.24 \%$ dan $80.68 \%$, secara statistik keduanya tidak berbeda nyata. Tetapi penurunan tingkat kadar air pada taraf $15 \%$ potensi tumbuh kakao turun drastis menjadi $20.27 \%$ yang berbeda nyata dengan potensi tumbuh dengan tingkat kadar air $25 \%\left(\mathrm{~K}_{2}\right)$ dan $30 \%\left(\mathrm{~K}_{3}\right)$ pada jenis bahan pengekstrak yang sama.

Sedangkan pada bahan pengekstrak kapur sirih $\left(\mathrm{M}_{3}\right)$ peningkatan tingkat kadar air benih kakao dapat meningkatkan potensi tumbuh benih kakao dari $56.38 \%$ pada kadar air $25 \%\left(\mathrm{~K}_{2}\right)$ menjadi $60.72 \%$ pada tingkat kadar air $30 \%\left(\mathrm{~K}_{1}\right)$, potensi tumbuh keduanya tidak berbeda nyata. Tetapi penurunan kadar air pada tingkat $15 \%\left(\mathrm{~K}_{3}\right)$ menyebabkan penurunan potensi tumbuh benih kakao menjadi $18.99 \%$ yang berbeda nyata dengan potensi tumbuh kakao menggunakan tingkat kadar air pada taraf $25 \%$ dan $30 \%$. 
Tabel 3. Rata-rata interaksi kombinasi bahan pengekstrak dan tingkat kadar air benih terhadap viabilitas dan vigor benih kakao

\begin{tabular}{|c|c|c|c|c|c|}
\hline \multirow{5}{*}{$\begin{array}{l}\text { Potensi } \\
\text { Tumbuh } \\
\text { (PT) }\end{array}$} & \multirow{2}{*}{$\begin{array}{c}\text { Bahan } \\
\text { Pengekstrak (M) }\end{array}$} & \multicolumn{3}{|c|}{ Kadar Air (K) } & \multirow{2}{*}{$\begin{array}{c}\mathrm{BNJ} \\
0.05\end{array}$} \\
\hline & & $\mathrm{K}_{1}$ & $\mathrm{~K}_{2}$ & $\mathrm{~K}_{3}$ & \\
\hline & $\mathrm{M}_{1}$ & $79.05 \mathrm{Bb}$ & $80.68 \mathrm{Bb}$ & $19.83 \mathrm{Aa}$ & \multirow{3}{*}{12.95} \\
\hline & $\mathrm{M}_{2}$ & $80.68 \mathrm{Bb}$ & $83.24 \mathrm{Bb}$ & $20.27 \mathrm{Aa}$ & \\
\hline & $\mathrm{M}_{3}$ & $60.72 \mathrm{Ba}$ & $56.38 \mathrm{Ba}$ & $18.99 \mathrm{Aa}$ & \\
\hline \multirow{5}{*}{$\begin{array}{c}\text { Daya } \\
\text { Berkecambah } \\
\text { (DB) }\end{array}$} & Bahan & \multicolumn{3}{|c|}{ Kadar Air (K) } & \multirow{2}{*}{$\begin{array}{c}\mathrm{BNJ} \\
0.05\end{array}$} \\
\hline & Pengekstrak (M) & $\mathrm{K}_{1}$ & $\mathrm{~K}_{2}$ & $\mathrm{~K}_{3}$ & \\
\hline & $\mathrm{M}_{1}$ & $63.51 \mathrm{Bb}$ & $57.87 \mathrm{Bb}$ & $14.80 \mathrm{Aa}$ & \multirow{3}{*}{5.75} \\
\hline & $\mathrm{M}_{2}$ & $73.92 \mathrm{Cc}$ & $67.52 \mathrm{Bc}$ & $17.71 \mathrm{Aa}$ & \\
\hline & $\mathrm{M}_{3}$ & $55.64 \mathrm{Ba}$ & $51.56 \mathrm{Ba}$ & $13.17 \mathrm{Aa}$ & \\
\hline \multirow{5}{*}{$\begin{array}{c}\text { Berat Kering } \\
\text { Kecambah } \\
\text { Normal } \\
(\mathrm{BKKN})\end{array}$} & Bahan & \multicolumn{3}{|c|}{ Kadar Air (K) } & $\mathrm{BNJ}$ \\
\hline & Pengekstrak (M) & $\mathrm{K}_{1}$ & $\mathrm{~K}_{2}$ & $\mathrm{~K}_{3}$ & 0.05 \\
\hline & $\mathrm{M}_{1}$ & $25.52 \mathrm{Ba}$ & $23.41 \mathrm{Bb}$ & $6.43 \mathrm{Aa}$ & \multirow{3}{*}{2.57} \\
\hline & $\mathrm{M}_{2}$ & $27.53 \mathrm{Bb}$ & $26.32 \mathrm{Bc}$ & $7.68 \mathrm{Aa}$ & \\
\hline & $\mathrm{M}_{3}$ & $23.38 \mathrm{Ca}$ & $13.24 \mathrm{Ba}$ & $5.64 \mathrm{Aa}$ & \\
\hline \multirow{5}{*}{$\begin{array}{c}\text { Kecepatan } \\
\text { Tumbuh } \\
(\mathrm{KCT})\end{array}$} & Bahan & \multicolumn{3}{|c|}{ Kadar Air (K) } & $\mathrm{BNJ}$ \\
\hline & Pengekstrak (M) & $\mathrm{K}_{1}$ & $\mathrm{~K}_{2}$ & $\mathrm{~K}_{3}$ & 0.05 \\
\hline & $\mathrm{M}_{1}$ & $13.29 \mathrm{Bb}$ & $12.00 \mathrm{Ba}$ & $3.62 \mathrm{Aab}$ & \multirow{3}{*}{0.98} \\
\hline & $\mathrm{M}_{2}$ & $14.49 \mathrm{Bc}$ & $13.89 \mathrm{Bb}$ & $3.97 \mathrm{Aab}$ & \\
\hline & $\mathrm{M}_{3}$ & $11.56 \mathrm{Ba}$ & $11.21 \mathrm{Ba}$ & $3.24 \mathrm{Aa}$ & \\
\hline \multirow{5}{*}{$\begin{array}{c}\text { Keserampakan } \\
\text { Tumbuh } \\
(\text { KST })\end{array}$} & Bahan & \multicolumn{3}{|c|}{ Kadar Air $(\mathrm{K})$} & BNJ \\
\hline & Pengekstrak (M) & $\mathrm{K}_{1}$ & $\mathrm{~K}_{2}$ & $\mathrm{~K}_{3}$ & 0.05 \\
\hline & $\mathrm{M}_{1}$ & $47.69 \mathrm{Cb}$ & $37.64 \mathrm{Ba}$ & $11.54 \mathrm{Aa}$ & \multirow{3}{*}{6.30} \\
\hline & $\mathrm{M}_{2}$ & $60.72 \mathrm{Bc}$ & $55.58 \mathrm{Bb}$ & $16.43 \mathrm{Aa}$ & \\
\hline & $\mathrm{M}_{3}$ & $36.70 \mathrm{Ba}$ & $36.79 \mathrm{Ba}$ & $11.54 \mathrm{Aa}$ & \\
\hline
\end{tabular}

Bila melihat respon potensi tumbuh akibat interaksi berbagai bahan pengekstrak pada berbagai tingkat kadar air menunjukkan pada tingkat kadar air $30 \%$ potensi tumbuh berbeda-beda untuk masing-masing bahan pengekstraksi, dimana ekstraksi dengan sekam $\left(\mathrm{M}_{1}\right)$ nilai potensi tumbuhnya adalah 79.05 , ekstraksi dengan serbuk gergaji $\left(\mathrm{M}_{2}\right)$ meningkat menjadi $80.68 \%$ secara statistik nilainya tidak berbeda nyata, tetapi potensi tumbuh berbeda nyata dengan benih yang di ekstrak dengan kapur sirih $\left(\mathrm{M}_{3}\right)$ yaitu dengan nilai $60.72 \%$, meskipun tingkat kadar airnya sama-sama $30 \%\left(\mathrm{~K}_{1}\right)$.

Pada tingkat kadar air $25 \%\left(\mathrm{~K}_{2}\right)$ nilai potensi tumbuh tertinggi terdapat pada bahan pengekstrak serbuk gergaji yaitu dengan nilai 83.24 dan potensi tumbuh mengalami penurunan pada ekstraksi menggunakan sekam yaitu dengan nilai 80.68 meskipun secara statistik tidak menunjukkan perbedaan yang nyata. Namun apabila diekstrak dengan menggunakan bahan pengekstrak dari bahan kapur sirih $\left(\mathrm{M}_{3}\right)$ nilai potensi tumbuh mengalami penurunan yang drastis 
yaitu 56.38 yang berbeda nyata dengan ekstraksi menggunakan serbuk gergaji $\left(\mathrm{M}_{2}\right)$ dan sekam $\left(\mathrm{M}_{1}\right)$. Akan tetapi pada tingkat kadar air $15 \%$ potensi tumbuh pada berbagai bahan pengekstrak tidak berbeda nyata

Respon daya berkecambah benih kakao akibat interaksi antara bahan pengekstrak dengan tingakat kadar air benih pada bahan pengekstrak arang sekam menunjukkan bahwa semakin tinggi kadar air benih, semakin tinggi daya berkecambah benih kakao. Pada benih dengan kadar air $25 \%\left(\mathrm{~K}_{2}\right)$ nilai rata-rata daya berkecambah pada interaksi tersebut adalah $57.87 \%$ meningkat menjadi $63.51 \%$ pada tingkat kadar air $30 \%\left(\mathrm{~K}_{1}\right)$ meskipun secara statistik keduanya tidak berbeda nyata. Tetapi bila kadar airnya diturunkan pada tingkat $15 \% \quad\left(\mathrm{~K}_{3}\right)$ maka daya berkecambah turun menjadi $14.80 \%$ yang berbeda nyata dengan daya berkecambah $\mathrm{K}_{1}$ dan $\mathrm{K}_{2}$ pada bahan pengekstrak yang sama.

Sedangkan penggunaan bahan pengekstrak yang menggunakan serbuk gergaji $\left(\mathrm{M}_{2}\right)$ menunjukkan bahwa semakin tinggi kadar air benih kakao semakin tinggi daya berkecambah benih kakao. Dimana pada kadar air $15 \%$ nilai daya berkecambah adalah $13.17 \%$ meningkat menjadi $51.56 \%$ pada tingkat kadar air $25 \%\left(\mathrm{~K}_{2}\right)$ kemudian meningkat menjadi $55.64 \%$ pada tingkat kadar air 30\%. Daya berkecambah $K_{1}$ dan $K_{2}$ tidak berbeda nyata, tetapi berbeda nyata pada daya berkecambah dengan kadar air $15 \%$ pada bahan pengekstrak benih yang sama $\left(\mathrm{M}_{3}\right)$.

Demikian pula halnya dengan penggunaan bahan pengekstrak dari kapur sirih $\left(\mathrm{M}_{3}\right)$ dimana kadar air benih pada taraf $30 \%$ memperoleh nilai daya berkecambah yang tinggi bila dibandingkan dengan kadar air 25\% $\left(\mathrm{K}_{2}\right)$ meskipun keduanya tidak menunjukkan perbedaan yang nyata, namun bila tingkat kadar airnya diturunkan pada taraf $15 \%$ $\left(\mathrm{K}_{3}\right)$ secara statistik nilai daya berkecambah menunjukkan perbedaan yang sangat nyata bila dibandingkan dengan perlakuan $\mathrm{K}_{1}$ dan $\mathrm{K}_{2}$.

Bila melihat daya berkecambah akibat interaksi berbagai bahan pengekstrak pada berbagai tingkat kadar air menunjukkan pada tingkat kadar air $30 \%$ nilai daya berkecambah paling baik terdapat pada ekstraksi serbuk gergaji, dimana perlakuan ekstraksi dengan menggunakan sekam $\left(\mathrm{M}_{1}\right)$ nilai potensi tumbuhnya adalah 79.05, pada ekstraksi dengan serbuk gergaji $\left(\mathrm{M}_{2}\right)$ meningkat menjadi $80.68 \%$ meskipun secara statistik nilainya tidak berbeda nyata, tetapi daya berkecambah berbeda nyata dengan benih yang di ekstrak dengan kapur sirih $\left(\mathrm{M}_{3}\right)$ yaitu dengan nilai $60.72 \%$, pada tingkat kadar airnya sama $30 \%\left(\mathrm{~K}_{1}\right)$.

Pada tingkat kadar air 25\% nilai daya berkecambah terbaik terdapat pada serbuk gergaji $(67.52 \%)$ namun tidak berbeda nyata dengan sekam $(57.87 \%)$ tetapi bila menggunakan kapur sirih (51.56\%) menunjukkan penurunan nilai daya berkecambah benih kakao, yang berbeda nyata bila dibandingkan dengan perlakuan $\mathbf{M}_{1}$ dan $\mathbf{M}_{2}$. Sedangkan nilai daya berkecambah pada tingkat kadar air 15\% menunjukkan bahwa penggunaan bahan pengekstrak dari bahan serbuk gergaji (17.71) memperoleh nilai terbaik dibanding dengan ekstraksi sekam (14.80) dan kapur sirih (13.17) dan secara statistik semua perlakuan tersebut tidak menunjukkan perbedaan.

Pada berat kering kecambah normal (BKKN) respon interaksi antara bahan pengekstrak dengan tingkat kadar air benih terlihat semakin tinggi tingkat kadar air benih kakao, berat kering kecambah normal semakin berat. Nilai rata-rata pada $\mathrm{K}_{3}$ adalah $6.43 \mathrm{~g}$ dan $\mathrm{K}_{2}$ senilai 23.41g dan $\mathrm{K}_{1}$ senilai 25.52 g. Pada perlakuan $\mathrm{K}_{2}$ dan $\mathrm{K}_{1}$ secara statistik tidak menunjukkan perbedaan yang nyata, tetapi berbeda nyata dengan perlakuan dengan kadar air $\mathrm{K}_{3}$. Demikian pula pada metode pengekstrak serbuk gergaji $\left(\mathrm{M}_{2}\right)$ dimana semakin tinggi kadar air, berat kering kecambah normal 
semakin tinggi. Pada tingkat kadar air 15\% $\left(\mathrm{K}_{3}\right)$ nilai berat kering kecambah normal adalah $7.8 \mathrm{~g}$ sedangkan pada tingkat kadar air benih $25 \%\left(\mathrm{~K}_{2}\right)$ senilai $26.32 \mathrm{~g}$ dan pada tingkat kadar air benih $30 \%$ senilai 27.53 g. Berat kering kecambah normal pada perlakuan $\mathrm{K}_{2}$ dan $\mathrm{K}_{1}$ tidak berbeda nyata pada penggunaan bahan pengekstrak serbuk gergaji $\left(\mathbf{M}_{2}\right)$, tetapi berbeda nyata dengan tingkat kadar air $15 \%\left(\mathrm{~K}_{3}\right)$ dengan bahan pengekstrak yang sama.

Bahan pengekstrak kapur sirih $\left(\mathrm{M}_{3}\right)$ menunjukkan dimana peningkatan kadar air juga meningkatkan nilai berat kering kecambah normal, dimana pada kadar air $15 \%\left(\mathrm{~K}_{3}\right)$ berat kering kecambah normal senilai $5.64 \mathrm{~g}$ meningkat menjadi 13.24 pada kadar air benih $25 \%\left(\mathrm{~K}_{2}\right)$ dan meningkat menjadi $33.38 \mathrm{~g}$ pada kadar air $30 \%$. Berat kering kecambah normal pada taraf $15 \%, 25 \%$, dan $30 \%$ berbeda nyata satu sama lain.

Adapun respon berat kering kecambah normal akibat interaksi antara bahan pengekstrak dengan tingkat kadar air benih tertentu terlihat bahwa pada kadar air $30 \%$ bahan pengekstrak serbuk gergaji $\left(\mathrm{M}_{2}\right)$ mempunyai berat kering kecambah normal tertinggi yang berbeda nyata dengan $M_{1}$ dan $M_{3}$ meskipun secara statistik nilainya tidak berbeda nyata. Sedangkan pada tingkat kadar air $25 \%\left(\mathrm{~K}_{2}\right)$ memperlihatkan berat kering kecambah normal yang berbeda pula, dimana nilai tertinggi terdapat pada ekstraksi serbuk gergaji $\left(M_{2}\right)$ yang berbeda nyata dengan $\mathrm{M}_{3}$ dan $\mathrm{M}_{1}$, berat kering kecambah normal pada $M_{1}$ berbeda nyata dengan $M_{3}$ pada tingkat kadar air yang sama. Sedangkan pada tingkat kadar air $15 \% \quad\left(\mathrm{~K}_{3}\right)$ pada berbagai bahan pengekstrak tidak memperlihatkan nilai yang berbeda nyata

Respon benih kakao akibat interaksi antara bahan pengekstrak dengan tingkat kadar air terhadap kecepatan tumbuh benih kakao terlihat bahwa kecepatan tumbuh semakin meningkat dengan meningkatnya kadar air benih. Pada tingkat kadar air benih $15 \%\left(\mathrm{~K}_{3}\right)$ nilai kecepatan tumbuhnya $3.62 \%$ meningkat menjadi $12 \%$ pada kadar air $25 \%\left(\mathrm{~K}_{2}\right)$ dan naik menjadi $13.29 \%$ pada tingkat kadar air 30\% $\left(\mathrm{K}_{1}\right)$ pada bahan pengekstrak yang sama $\left(\mathrm{K}_{1}\right)$. Sedangkan kecepatan tumbuh benih kakao dengan tingkat kadar air $15 \%\left(\mathrm{~K}_{3}\right)$ berbeda nyata dengan kecepatan tumbuh benih kakao dengan tingkat kadar air benih 25\% $\left(\mathrm{K}_{2}\right)$ dan $30 \%\left(\mathrm{~K}_{1}\right)$, sedangkan pada $\mathrm{K}_{1}$ dan $\mathrm{K}_{2}$ secara stratistik tidak berbeda nyata pada pengaruh bahan pengekstrak arang sekam $\left(\mathrm{M}_{1}\right)$.

Pada perlakuan ekstraksi menggunakan serbuk gergaji $\left(\mathrm{M}_{2}\right)$ menunjukkan kecepatan tumbuh benih kakao semakin meningkat dengan meningkatnya kadar air, dimana pada kadar air $15 \%$ nilai kecepatan tumbuh adalah $3.79 \%$ meningkat menjadi $13.98 \%$ pada kadar air $25 \%\left(\mathrm{~K}_{2}\right)$ dan naik menjadi $14.49 \%$ pada kadar air 30\% dengan bahan pengekstrak yang sama $\left(\mathrm{M}_{2}\right)$. Demikian pula halnya pada bahan pengekstrak menggunakan kapur sirih $\left(\mathrm{M}_{3}\right)$, dimana peningkatan kadar air meningkatkan persentase kecepatan tumbuh benih kakao. Pada kadar air 15\% kecepatan tumbuh senilai $3.24 \%$ /etmal menjadi $13.21 \%$ /etmal pada tingkat kadar air 25\% $\left(\mathrm{K}_{2}\right)$ dan meningkat menjadi $11.56 \%$ pada tingkat kadar air 30\%. Kecepatan tumbuh benih kakao tingkat kadar air 25\% dan 30 $\%$ tidak berbeda nyata, tetapi berbeda nyata pada tingkat kadar air $15 \%$ pada bahan pengekstrak yang sama $\left(\mathrm{M}_{3}\right)$.

Respon masing-masing tingkat kadar air pada berbagai bahan pengekstrak terlihat tingkat bahwa kadar air 30\% tertinggi terdapat pada bahan pengekstrak serbuk gergaji $\left(\mathrm{M}_{2}\right)$ yang berbeda nyata dengan bahan pengekstrak dari sekam $\left(\mathrm{M}_{1}\right)$ dan kapur sirih $\left(\mathrm{M}_{3}\right)$ pada tingkat kadar air yang sama (30\%). Sedangkan pada kadar air $25 \%$ kecepatan tumbuh tertinggi terdapat pada metode ekstraksi serbuk gergaji $\left(\mathbf{M}_{2}\right)$ yang berbeda nyata dengan kecepatan tumbuh menggunakan bahan pengekstrak sekam $\left(\mathrm{M}_{1}\right)$ dan kapur sirih 
$\left(\mathrm{M}_{3}\right)$, tetapi perlakuan $\mathrm{M}_{1}$ tidak berbeda nyata dengan $\mathrm{M}_{2}$ pada kadar air yang sama. Pada kadar air 15\% kecepatan tumbuh tertinggi terdapat pada bahan pengekstrak serbuk gergaji $\left(\mathrm{M}_{2}\right)$ yang berbeda nyata dengan bahan pengekstrak dari sekam $\left(\mathrm{M}_{1}\right)$ dan kapur sirih $\left(\mathrm{M}_{3}\right)$, tetapi secara statistik perlakuan $\mathrm{M}_{1}, \mathrm{M}_{2}$, dan $\mathrm{M}_{3}$ tidak berbeda nyata.

Respon benih kakao akibat interaksi antara bahan pengekstrak dan tingkat kadar air terhadap keserampakan tumbuh $\left(\mathrm{K}_{\mathrm{ST}}\right)$ terlihat bahwa pada ekstraksi menggunakan bahan sekam $\left(\mathrm{M}_{1}\right)$ menunjukkan semakin tinggi tingkat kadar air maka nilai keserampakan tumbuh juga meningkat, dimana pada tingkat kadar air $15 \%\left(\mathrm{~K}_{3}\right)$ keserampakan tumbuh $15.54 \%$ menjadi $37.64 \%$ pada tingkat kadar air $25 \%$ dan naik menjadi $47.69 \%$ pada tingkat kadar air 30\%, ketiganya berbeda nyata pada perlakuan bahan pengekstrak yang sama $\left(\mathrm{M}_{1}\right)$. Demikian pada bahan pengekstrak menggunakan serbuk gergaji $\left(\mathrm{M}_{2}\right)$, peningkatan tingkat kadar air benih dapat meningkatkan keserampakan tumbuh benih kakao, dimana pada tingkat kadar air $15 \% \quad\left(\mathrm{~K}_{3}\right)$ rata-rata nilainya $16.43 \%$ menjadi $55.58 \%$ pada tingkat kadar air $25 \%\left(\mathrm{~K}_{2}\right)$ dan naik menjadi $60.72 \%$ pada tingkat kadar air 30\%. Keserampakan tumbuh pada perlakuan $\mathrm{K}_{1}$ dan $\mathrm{K}_{2}$ tidak berbeda nyata, tetapi berbeda nyata pada tingkat kadar air benih $15 \%$ pada bahan pengekstrak yang sama $\left(\mathrm{M}_{2}\right)$.

Hal serupa juga terlihat pada bahan pengekstrak kapur sirih $\left(\mathrm{M}_{3}\right)$, dimana peningkatan kadar air pada taraf tertentu dapat meningkatkan keserampakan tumbuh benih kakao. Pada tingkat kadar air 15\% nilai keserampakan tumbuh $11.54 \%$ naik menjadi $36.79 \%$ pada $\mathrm{K}_{2}$ dan 36.70 pada $\mathrm{K}_{3}$. Keserampakan tumbuh pada $\mathrm{K}_{1}$ dan $\mathrm{K}_{2}$ tidak berbeda nyata, tetapi berbeda nyata dengan keserampakan tumbuh $\mathrm{K}_{3}$ pada bahan pengekstrak yang sama.

Bila dilihat pada respon keserampakan tumbuh masing-masing benih kakao pada berbagai bahan pengekstrak terlihat pada tingkat kadar air $30 \%$ keserampakan tumbuh tertinggi terdapat pada bahan pengekstrak serbuk gergaji $\left(\mathrm{M}_{2}\right)$ yaitu $60.72 \%$ yang berbeda nyata dengan keserampakan tumbuh pada bahan pengekstrak sekam $\left(\mathrm{M}_{1}\right)$ dan kapur sirih $\left(\mathrm{M}_{3}\right)$ pada tingkat kadar air yang sama $\left(\mathrm{K}_{1}\right)$. Sedangkan pada kadar air $25 \%$ keserampakan tumbuh tertinggi terdapat pada bahan pengekstrak serbuk gergaji $\left(\mathrm{M}_{2}\right)$ yaitu $55.58 \%$ yang berbeda nyata dengan keserampakan tumbuh menggunakan bahan pengekstrak sekam $\left(\mathrm{M}_{1}\right)$ dan kapur sirih $\left(\mathrm{M}_{3}\right)$ pada tingkat kadar air yang sama (25\%).

Sedang pada tingkat kadar air $15 \%$ tertinggi terdapat pada bahan pengekstrak serbuk gergaji $\left(\mathrm{M}_{2}\right)$ yaitu $16.43 \%$, yang tidak berbeda nyata dengan keserampakan tumbuh menggunakan bahan pengekstrak sekam (11.54) dan kapur sirih (11.54) pada tingkat kadar air yang sama $\left(\mathrm{K}_{3}\right)$.

Terdapat interaksi yang sangat nyata antara bahan ekstraksi dan tingkat kadar air terhadap viabilitas dan vigor benih kakao yaitu terhadap daya berkecambah (DB), berat kering kecambah normal (BKKN), kecepatan tumbuh $\left(\mathrm{K}_{\mathrm{CT}}\right)$, keserampakan tumbuh $\left(\mathrm{K}_{\mathrm{ST}}\right)$, berpengaruh tidak nyata terhadap waktu yang dibutuhkan untuk mencapai $50 \%$ total perkecambahan (T $50 \%$ ) dan indeks vigor (IV). Tolok ukur tersebut berbeda untuk masing-masing bahan pengekstrak dan tingkat kadar air benih yang digunakan. Berdasarkan pengaruh bahan pengekstrak benih kakao pada berbagai tolok ukur viabilitas dan vigor benih menunjukkan bahwa ekstraksi yang paling baik adalah berasal dari bahan pengekstrak serbuk gergaji $\left(\mathrm{M}_{2}\right)$, sedangkan tingkat kadar air yang menunjukkan nilai terbaik dijumpai pada $30 \%\left(\mathrm{~K}_{1}\right)$. Namun ekstraksi menggunakan sekam sudah cukup efektif untuk meningkatkan viabilitas dan vigor benih kakao, begitu juga dengan tingkat kadar air $25 \%$ dengan kata lain penurunan tingkat kadar air kakao sampai taraf 25\% masih menunjukkan viabilitas benih yang tinggi. 
Tingginya viabilitas dan vigor pada benih dengan menggunakan bahan pengekstrak serbuk gergaji dengan tingkat kadar air pada taraf $30 \%$ diperkirakan karena benih yang di ekstrak menggunakan bahan serbuk gergaji mampu membersihkan benih dari penghalang perkecambahan yang disebabkan oleh lapisan pulp, selain itu ekstraksi menggunakan serbuk gergaji dapat melindungi benih dari kerusakan mekanis serta hilangnya pulp dari permukaan benih juga dapat mencegah benih dari serangan hama dan penyakit. Bewley dan Black (1985) menyatakan pulp merupakan penghalang dalam mengatur sirkulasi dan gas lainnya kedalam dan keluar benih. Selain itu lendir kakao disukai semut dan sebagai media yang baik bagi cendawan. Lendir-lendir akan mengalami fermentasi dan dapat menghambat masuknya oksigen dan air sehingga dapat menurunkan viabilitas benih.

Kandungan air benih merupakan kendala utama dalam mempertahankan mutu benih kakao yang bersifat rekalsitran. Penelitian ini menunjukkan kadar air pada taraf $30 \%$ memiliki viabilitas dan vigor paling tinggi di banding taraf tingkat kadar air lainnya. Hal ini erat kaitannya dengan sifat benih rekalsitran yang memerlukan tingkat kadar air tinggi untuk melakukan aktivitas perkecambahannya. Fungsi air bagi benih adalah mengisi semua bagian dari tiap sel, merupakan medium tempat berlangsungnya transport nutrient, reaksireaksi enzimatik metabolisme sel dan transfer energi kimia. Oleh karena itu semua aspek dari struktur dan fungsi sel harus beradaptasi dengan sifat-sifat fisik dan kimia air. Air dan produk ionisasinya, ion $\mathrm{H}^{+}$dan $\mathrm{OH}^{-}$sangat mempengaruhi sifat dari berbagai komponen penting sel seperti enzim, protein, asam nukleat dan lipid. Sebagai contoh enzim katalitik amat tergantung pada konsentrasi ion $\mathrm{H}^{+}$dan $\mathrm{OH}^{-}$(Salisbury dan Ross 1995). Air tidak hanya penting sebagai pelarut dalam reaksi-reaksi biokimia tetapi juga untuk mengatur keseimbangan struktur sel, terutama membran (Adimargono 1997).

\section{KESIMPULAN}

Jenis benih berpengaruh terhadap viabilitas dan vigor benih kakao. Ekstraksi benih kakao yang berasal dari serbuk gergaji menghasilkan viabilitas dan vigor benih terbaik. Tingkat kadar air berpengaruh terhadap viabilitas dan vigor benih kakao. Kadar air 30\% menghasilkan viabilitas dan vigor terbaik. Terdapat interaksi antara behan pengekstrak benih dan tingkat kadar air benih kakao. Benih yang diekstrak dengan menggunakan serbuk gergaji dengan tingkat kadar air $30 \%$ memiliki viabilitas dan vigor tertinggi.

\section{DAFTAR PUSTAKA}

Adimargono, S. 1997. Recalsitrant seeds, identification and storage [thesis]. Deventer: Larenstein International Agriculture Collage

Bewley JD, M Black. 1985. Seed: Physiologi of Development and Germinator. New York and London: Plenum Press. $2^{\text {nd }}$ Edition. $445 \mathrm{p}$

Bewley JD, M Black. 1994. Seed: Physiologi of Development and Germinator. New York and London: Plenum Press. $3^{\text {nd }}$ Edition. 367 p.

Bonner FT. 1996. Response to drying of recalsitrant seed of Quercus nigr L. Ann. Bot. 78:181-187

Chin HF, M Azis, BB Ang, S Hamzah. 1981. The Effect of moisture and temperature on the ultra structure and viability of seed of Hevea brasiliensis. Seeds Science and Technology. 9:411-422

Chin HF. 1990. Germination. P. 38-52. In H.F. Chin and E. H. Robert 
(Eds.). Recalcitrant Crop Seeds. Kuala Lumpur: Trop. Press. SDN BHD

Copeland LO, MB McDonald. 1995. Seed Science and Technology. New York(USA): Chapman and Hall Press. 409 p

Hii CL, CL Law, S Suzannah, Misnawi, M Cloke. 2009. Polyphenols in cocoa (Theobroma cacao L.). Asian Journal of Food and AgroIndustry

Hor YL, HF Chin, MZ Karim. 1984. The Effect of seed moisture and storage temperature on the storability of cacao (Theobroma cacao L) seeds. Seed Sci Technol. 12:415-420

Ibanez IM, Cases. 1963. The effect of sugars and alcohol on endogenous: respiration in cacao embryios. Turrialba. 13 (4) : 209-212

Katriani. 2010. Penanganan dan Penyimpanan Benih Rekalsitran [internet]. [diunduh pada 2013 Maret 13]. Tersedia pada : http://www.

Unhas.ac.id/pertanian/indek

2.php? option=com docoman dan task $=$ doc view dan gi=147 dan hemid $=75$

King MW, Roberts EH. 1979. The storage of Recalcitrant Seeds Achievements and Possible Approaches. Rome: IBPGRsecretarial

King MW, Roberts. 1980. The Characteristic Roberts (Eds). Recalsitrant Crop Seed. Kuala Lumpur: Trop. Press SDN BHD

Kuswanto H. 2005. Teknologi Pemrosesan, Pengemasan dan Penyimpanan Benih. Yogyakarta (ID): Kanisius

Pammenter NW, V Greggains, JL Kioko, J Wesley-Smitth, P Berjak, FinchSavage WE. 1998. Effeck of differential drying rates on viability retention of recalcitrant seeds of ekerbigia capensis. Seed Sci. and Technol. 8(4) : 463-437p

Pranoto H, SW Mugnisyah, E Murniati. 1990. Biologi Benih. Bogor(ID): IPB. 137 hal.

Pusat Penelitian Kopi dan Kakao Indonesia. 2004. Panduan Lengkap Budidaya Kakao. Jakarta(ID): Agromania Pustaka

Robi A. 1996. Pengaruh kadar air awal terhadap penurunan vigor dan upaya invigorasi terhadap viabilitas benih kakao (Theobroma cacao L.) [skripsi]. Bogor(ID): Faperta IPB.

Salibusry FB, CW Ross. 1995. Fisiologi Tumbuhan. Lukman DR, Sumaryono, penerjemah. Bandung(ID): ITB. 343 hal

Siregar THS, Riyadi, L Nuraeni. 2000. Budidaya, Pengolahan dan Pemasaran Cokelat. Jakarta(ID): Penebar Swadaya

Soetisna U, King MW, Roberts EH. 1985. Germinator tests recomandation for estimating the viability of moist or dri seeds of lemon (Citrus limon) and Lime $(C$. aurantifolia). Seed Sci. and Tecnol. 13:87-110

Sukarman, D Rusmin. 2002. Penanganan benih rekalsitran. Buletin Plasma Nutfah. 6: 7-15

Sunanto H. 2002. Budidaya, Pengolahan dan Aspek Ekonominya. Yogyakarta(ID): Kanisius. 130 hlm.

Supianti P. 2000. Studi cara ekstraksi benih terhadap viabilitas benih jeruk besar dan serangan cendawan selama periode simpan [skripsi]. Bogor(ID): IPB

Sutopo L. 2002. Teknologi Benih. Jakarta(ID): PT. Raja Grafindo Persada

Swarbrick JT. 1965. Storage of cacao seeds. Exp. Agtic. 10:201-207 
Winarsih. 1994. Pengaruh kadar air benih, lama goncangan / transportasi serta GA3 dan NAA terhadap viabilitas benih damar (Agathis loranthifolia Salisv) [skripsi]. Bogor(ID): Faperta IPB. 